\title{
Determinants of occupational multisite musculoskeletal disorders: a cross sectional study among 254 patients
}

\author{
A. Mahfoudh, K. Fennani, M. Akrout, K. Taoufik \\ Department of Occupational Health \& Ergonomics, Faculty of Medicine of Monastir, \\ University of Monastir, Tunisia.
}

\section{SUMMARY}

The aim was to describe the profile of workers with occupational multi-site musculoskeletal disorders (MSMSD) and study the relationship between these lesions and socio-professional factors.

This is a cross-sectional study involving 254 subjects with occupational musculoskeletal disorders (MSD), identified in the Department of Occupational Medicine at the University Hospital of Mahdia, in Tunisia, over a period of 10 years from 2005 to 2014. The study population was subdivided into two groups; mono-site MSD and multi-site ( $\geq 2$ sites) groups. Data collection was based on a questionnaire prepared beforehand and covered the description of sociodemographic and professional characteristics. To study psychosocial constraints at work, we have used the Karasek questionnaire.

MS-MSD was correlated to the number of dependent children $(\mathrm{p}=0.02)$, job/place of work $(\mathrm{p}=0.00)$, qualification $(\mathrm{p}=0.02)$, taking a rest period $(\mathrm{p}=0.03)$, decision latitude $(\mathrm{p}=0.00)$, mental demands $(\mathrm{p}=0.002)$, social support $(\mathrm{p}=0.00)$ and job stress $(\mathrm{p}=0.04)$. After binary logistic regression, MS-MSD depended significantly on the number of dependent children $(\mathrm{p}=0.013 ; \mathrm{OR}=0,33 ; \mathrm{IC}=0,17-0,83)$, working spouse $(\mathrm{p}=0.05 ; \mathrm{OR}=0.35$; $\mathrm{IC}=0.12-0.99)$, job/place of work $(\mathrm{p}=0.00 ; \mathrm{OR}=4.16 ; \mathrm{IC}=1.95-8.88)$, qualification $(\mathrm{p}=0.008 ; \mathrm{OR}=0.28$; $\mathrm{IC}=0.11-0.72)$, taking a break during work $(\mathrm{p}=0.04 ; \mathrm{OR}=3.10 ; \mathrm{IC}=1.04-9.22)$ and social support $(\mathrm{p}=0.00$; $\mathrm{OR}=7,1 ; \mathrm{IC}=1,9-25,3$ ).

When individual risk factors are fixed, the prevention of MS-MSD must target modifiable levers, related to the professional environment of the employees.

Key words: Multisite; Musculoskeletal disorders; Occupational disease; Risk factor.

\section{INTRODUCTION}

$\mathrm{M}$ SD are the leading cause of morbidity and disability in the European Union and represent a work problem in different countries $(1,2)$. According to Eurostat, the Statistical Office of the European Community, MSD represent the most widespread and costly occupational health problems in Europe affecting about 45 million workers. In France, MSD are the principal cause of occupational diseases, with an annual increase of $18 \%$ over the past 10 years. In addition, claims for benefits increase from year to year and represent $76 \%$ of occupational illnesses compensated in 2015 (3). In Tunisia, during the last decade, the number of MSD declared as occupational dis- eases has increased. Indeed, this number has augmented from 15 in 1995 to 155 in 2004 and 287 in 2011. The most affected sectors are electronics, confection and food industries (2).

These disorders constitute a major public health problem and an occupational health challenge. Consequently, a better understanding of the mechanisms responsible for the onset or progression of these lesions is required. Recent studies support a more comprehensive approach to musculoskeletal disorders, analyzing the extent of musculoskeletal symptoms and the number of symptomatic anatomical sites rather than a particular site $(4,5)$. This definition seems to be adopted by the American College of Rheumatology $(6,7)$. 
Although several teams have begun to describe the profile of subjects with MS-MSD (8-11), very few studies have targeted the working population.

These considerations led us to carry out this study, which aims to describe the profile of workers with MS-MSD and to study the relationship between the appearance of these lesions and socio-professional constraints at work.

\section{MATERIALS AND METHODS}

\section{Patients}

This is a cross-sectional study of subjects with occupational MS-MSD, identified at the Department of Occupational Medicine at the University Hospital of Mahdia in Tunisia over a period of 10 years from 2005 to 2014 .

Included in this study were patients in professional activities who had benefited from a declaration of MS-MSD as an occupational disease; i.e. occupational exposure to biomechanical constraint had been assessed. Consequently, the anatomical sites studied were shoulders, arms, elbows, forearms, hands and wrists that had been compensated as occupational damage in conformity with Law No. 94-28 of 21 February 1994 according to Tunisian legislation (12).

A MS-MS disease is defined by the presence of symptoms affecting at least two different anatomical sites and a bilateral lesion is considered as a single pathology. During the study period, 254 subjects were counted; subdivided into two groups. A first group was composed of patients with a single musculoskeletal lesion. The second group represented patients with at least two affected sites.

\section{Methods}

Data collection was based on a fact sheet prepared beforehand and completed by an investigating doctor. Clinical and paraclinical data were collected from records. Some information was collected during telephone contacts.

The questionnaire involved information under three headings; a description of so- ciodemographic data (gender, age, BMI, family situation, number of dependent children, medical and surgical history...), occupational data (labor market, job position, qualification, job tenure...) and psychosocial constraints. We therefore used the Karasek questionnaire. This questionnaire was conceived by the American sociologist and psychologist Robert Karasek in 1979. It is a questionnaire that evaluates for each employee the intensity of mental demands to which he is subject, the decisional latitude at his disposal and the social support he receives at his place of work. The questionnaire consists of 26 questions divided into three sections: Nine for decisional latitude, nine for mental requirements and eight for social support. The proposed answers are: strongly disagree, disagree, agree perfectly, agree, which allows them to be scored from 1 to 4 and to calculate a score for each of the three sections (13).

Job-stress is defined as a situation or score of mental demands greater than 20, decision latitude below 71 and a social support score of less than 24 (4).

\section{Statistical study}

We studied frequencies and percentages for qualitative variables and averages, medians, standard deviations and extremes for quantitative variables.

To compare averages, we used the $t$ test of Student and the $f$ test of ANOVA. For the comparison of frequencies, we performed the chi2 test.

To study predictive factors of multi-site occupational MSD, we performed a multiple binary regression. The inclusion of independent variables in the regression models was done when their degree of significance was less than 0.2 . The threshold of significance $\mathrm{p}$ was set at 0.05 .

\section{RESULTS}

\section{General characteristics}

Sociodemographic characteristics

The mean age of the study population was $42.8 \pm 8.4$ years. A female predominance was noted with a sex ratio of 0.13 . The 
average of the BMI was $25 \pm 2.6 \mathrm{~kg} / \mathrm{m}^{2}$. Nearly half of the patients were overweight (136 patients).

Most patients were right-handed $(88.2 \%)$. Married workers represented $73.6 \%$ and more than half of them had more than one dependent child (77.2\%). The spouse worked in $63.4 \%$ of cases and $55.6 \%$ of these had temporary or occasional work. In this study, $94.9 \%$ of the patients did not participate in leisure activities. The average distance to and from the work place was

Table I - Influence of sociodemographic characteristics on MS-MSD, univariate analysis.

\begin{tabular}{|c|c|c|c|c|c|c|}
\hline & \multicolumn{2}{|c|}{1 site } & \multicolumn{2}{|c|}{$\geq 2$ sites } & \multirow{2}{*}{$p$} \\
\hline & & $\mathrm{N}$ & $\%$ & $\mathrm{~N}$ & $\%$ & \\
\hline \multirow{2}{*}{ Gender } & Male & 26 & 12.2 & 4 & 9.8 & \multirow{2}{*}{0.85} \\
\hline & Female & 187 & 87.8 & 37 & 90.2 & \\
\hline \multirow{3}{*}{ Age (years) } & $<35$ & 39 & 18.3 & 7 & 17.1 & \multirow{3}{*}{0.22} \\
\hline & $35-50$ & 132 & 60 & 21 & 51.2 & \\
\hline & $>50$ & 42 & 19.7 & 13 & 31.7 & \\
\hline \multirow{4}{*}{$B M I\left(\mathrm{~kg} / \mathrm{m}^{2}\right)$} & $<20$ & 1 & 0.5 & 0 & 0 & \multirow{4}{*}{0.55} \\
\hline & $20-25$ & 120 & 56.3 & 27 & 65.9 & \\
\hline & $25-30$ & 87 & 40.8 & 14 & 34.1 & \\
\hline & $>30$ & 5 & 2.3 & 0 & 0 & \\
\hline \multirow[b]{2}{*}{ Dexterity } & Right-handed & 189 & 88.7 & 35 & 85.4 & \multirow[b]{2}{*}{0.72} \\
\hline & $\begin{array}{l}\text { Left-handed } \\
\text { or ambidextrous }\end{array}$ & 24 & 11.3 & 6 & 14.6 & \\
\hline
\end{tabular}

\begin{tabular}{|l|l|c|c|c|c|c|}
\hline \multirow{2}{*}{$\begin{array}{l}\text { Matrimonial } \\
\text { status }\end{array}$} & Married & 154 & 72.3 & 33 & 80.5 & \multirow{2}{*}{0.37} \\
\cline { 2 - 6 } & Others & 59 & 2.7 & 8 & 19.5 & \\
\hline \multirow{2}{*}{$\begin{array}{l}\text { Number of } \\
\text { children in care }\end{array}$} & $\leq 3$ & 184 & 86.4 & 29 & 70.7 & \multirow{2}{*}{0.02} \\
\cline { 2 - 6 } & $>3$ & 29 & 13.6 & 12 & 29.3 & \\
\hline \multirow{2}{*}{ Spouse's work } & Stable & 65 & 48.2 & 7 & 26.9 & \multirow{2}{*}{0,08} \\
\cline { 2 - 6 } & Not stable & 70 & 51.8 & 19 & 73.1 & \\
\hline \multirow{2}{*}{ Leisure activity } & Yes & 13 & 6.1 & 0 & 0 & \multirow{2}{*}{0.21} \\
\cline { 2 - 6 } & No & 200 & 93.9 & 41 & 100 & \\
\hline \multirow{2}{*}{$\begin{array}{l}\text { Distance of travel } \\
\text { residence- } \\
\text { workplace }\end{array}$} & $\leq 5 \mathrm{~km}$ & 163 & 76.5 & 34 & 82.9 & \multirow{2}{*}{0.48} \\
\cline { 2 - 6 } & $>5 \mathrm{~km}$ & 50 & 23.5 & 7 & 17.1 & \\
\hline \multirow{3}{*}{ Means of travel } & On foot & 109 & 51.4 & 18 & 41.5 & \multirow{2}{*}{0.31} \\
\cline { 2 - 6 } & $\begin{array}{l}\text { Public or private } \\
\text { transport means }\end{array}$ & 103 & 48.6 & 24 & 58.5 & \\
\hline \multirow{2}{*}{ Medical history } & Yes & 83 & 39 & 20 & 48.8 & \multirow{2}{*}{0.31} \\
\cline { 2 - 6 } & No & 130 & 61 & 21 & 51.2 & \\
\hline
\end{tabular}

$4.17 \pm 3.36 \mathrm{~km} .22 .4 \%$ of these moved more than $5 \mathrm{~km}$ to get to work. The main pre-existing morbidities were metabolic diseases $(18.5 \%)$, followed by hypertension $(9.1 \%)$ and hypothyroidism $(4.7 \%)$.

\section{Occupational characteristics}

In this study, $78 \%$ of patients worked in the confection sector. The position of worker on machine was predominant with a percentage of $41.3 \%$.

The average service length was $21.33 \pm 7.64$ years. The studied population was characterized by the predominance of employees $(83.9 \%)$, followed by state officials (15.4\%).

The average of work hours per day were $8.15 \pm 1.3$ hours with extremes ranging from 4 to 12 hours, and $39 \%$ of patients worked overtime for $80 \pm 60 \mathrm{~min}$. Officeholders represented $85 \%$ of study population and $16.5 \%$ of patients had a work break period.

\section{Psychosocial stress at work}

The mean social support score was $17.4 \pm 8.5$ and $42.4 \%$ subjects had a social support score of less than 24 .

A score of mental requirements greater than 20 was noted in $87.9 \%$ with an average score of $24 \pm 2.69$. The mean decisional latitude score was $31.18 \pm 3.6$ and $99 \%$ had decision latitude of less than 71. Most patients were in a job-stress situation (90.4\%).

\section{Musculoskeletal disorders}

MSD identified were rotator cuff tendonitis (34.3\%), carpal tunnel syndrome (54.3\%), epicondylitis (28.3\%), De Quervain tendonitis $(4.3 \%)$. In this study, $16.9 \%$ of patients had multi-sites pathologies.

\section{Univariate analysis}

In our study, MS-MSD was significantly associated with the number of dependent children $(\mathrm{p}=0.02)$, workplace $(\mathrm{p}=0.00)$, occupational qualification ( $\mathrm{p}=0.02)$, work-related rest periods $(p=0.03)$ and leaving the work place $(\mathrm{p}=0.05)$. Similarly, we found a statistically significant relationship between the different aspects of psychosocial stresses at work and MS-MSD (Tables I and II). 


\section{Multivariate study}

Following a binary logistic regression, MSMSD was significantly associated with a number of dependent children greater than three, instability of spouse's work, unqualified employees, clothing machine workers and lack of social support at work. Moreover, the possibility to take a period of rest during work was a protective factor against occupational MS-MSD (Table III).

\section{DISCUSSION}

Musculoskeletal disorders represent a widespread problem in the general population as well as in the workplace. In this study, we investigated individual and professional determinants in relation to multisite appearances of occupational MSD.

The population studied was characterized by a clear female predominance $(88 \%)$. This prevalence is well described in the literature and may be explained by a difference in working conditions between the two genders $(14,8)$. Indeed, women are often involved in monotonous and detailed repetitive tasks, causing localized constraints on extremities (15). In addition, domestic responsibilities are mentioned as risk factors which worsen MSD, since they often lead to an inability of the subjects to take proper care of themselves (e.g., inability to take rest due to domestic tasks) (16).

The mean age of the population studied was $42.8 \pm 8.4$ years with a slight increase in the frequency of multi-site involvement in subjects older than 50 years. However, this variable is not associated with the risk of MS-MSD. These findings are contrary to those of the literature $(10,17)$. In fact, the increase of MS-MSD prevalence with age may be explained by wear of anatomical textures with age such as decreased muscle strength, bone fragility, loosening of joint ligaments and thinning of the cartilage (18). This may explain the increasing trend in the incidence of MS-MSD noted in the elderly in our study.

The association of musculoskeletal disorders and overweight is well documented in the literature $(19,7)$. Kim JH's study,
Table II - Influence of professional characteristics on MS-MSD, univariate analysis.

\begin{tabular}{|c|c|c|c|c|c|c|}
\hline & \multicolumn{2}{|c|}{1 site } & \multicolumn{2}{|c|}{$\geq 2$ sites } & \multirow{2}{*}{$p$} \\
\hline & & $\mathbf{N}$ & $\%$ & $\mathbf{N}$ & $\%$ & \\
\hline \multirow{2}{*}{ Industrial sector } & Confection & 162 & 76.1 & 36 & 87.8 & \multirow{2}{*}{0.14} \\
\hline & Others & 51 & 23.9 & 5 & 12.2 & \\
\hline \multirow[t]{2}{*}{ Job } & $\begin{array}{l}\text { Clothing machine } \\
\text { worker }\end{array}$ & 76 & 35.7 & 29 & 70.7 & \multirow[t]{2}{*}{0.00} \\
\hline & Others & 137 & 64.3 & 12 & 29.3 & \\
\hline \multirow{2}{*}{$\begin{array}{l}\text { Professional } \\
\text { qualification }\end{array}$} & Qualified & 132 & 62 & 17 & 41.5 & \multirow{2}{*}{0.02} \\
\hline & Unqualified & 81 & 38 & 24 & 58.5 & \\
\hline \multirow{2}{*}{$\begin{array}{l}\text { Professional } \\
\text { category }\end{array}$} & Salaried & 183 & 85.9 & 32 & 78 & \multirow{2}{*}{0.29} \\
\hline & Official & 30 & 14.1 & 9 & 22 & \\
\hline \multirow{3}{*}{$\begin{array}{l}\text { Professional } \\
\text { seniority (years) }\end{array}$} & $<5$ & 2 & 0.9 & 1 & 2.4 & \multirow{3}{*}{0.63} \\
\hline & $5-20$ & 104 & 48.8 & 18 & 43.9 & \\
\hline & (1) & 107 & 50.2 & 22 & 53.7 & \\
\hline \multirow{2}{*}{$\begin{array}{l}\text { Duration of work } \\
\text { (hours) }\end{array}$} & $\leq 8$ & 109 & 51.2 & 26 & 63.4 & \multirow{2}{*}{0.2} \\
\hline & $>8$ & 104 & 48.8 & 15 & 36.6 & \\
\hline \multirow{2}{*}{ Work schedule } & $\begin{array}{l}\text { Fixed work } \\
\text { schedule }\end{array}$ & 132 & 62 & 21 & 51.2 & \multirow[t]{2}{*}{0.26} \\
\hline & Shift work & 81 & 38 & 20 & 48.8 & \\
\hline \multirow{2}{*}{$\begin{array}{l}\text { Employment } \\
\text { contract }\end{array}$} & Titular & 183 & 85.9 & 33 & 80.5 & \multirow{2}{*}{0.51} \\
\hline & Contractual & 30 & 14.1 & 8 & 19.5 & \\
\hline \multirow{2}{*}{$\begin{array}{l}\text { Taking a rest } \\
\text { period during } \\
\text { work }\end{array}$} & Yes & 30 & 71.4 & 12 & 29.3 & \multirow{2}{*}{0.03} \\
\hline & No & 183 & 85.9 & 29 & 70.7 & \\
\hline \multirow{2}{*}{ Period of rest } & $\leq 10 \min$ & 16 & 51.6 & 3 & 27.3 & \multirow{2}{*}{0.21} \\
\hline & $>10 \mathrm{~min}$ & 15 & 48.4 & 8 & 72.7 & \\
\hline \multirow{3}{*}{$\begin{array}{l}\text { Psychosocial } \\
\text { constraints }\end{array}$} & Decisional latitude & - & - & - & - & 0.004 \\
\hline & $\begin{array}{l}\text { Mental } \\
\text { requirements }\end{array}$ & - & - & - & - & 0.002 \\
\hline & Social support & - & - & - & - & 0.001 \\
\hline \multirow{2}{*}{ Job-stress } & Yes & 189 & 88.7 & 41 & 100 & \multirow{2}{*}{0.04} \\
\hline & No & 24 & 11.3 & 0 & 0 & \\
\hline
\end{tabular}

for example, conducted among 189 cameramen, showed a significant correlation between MS-MSD with a high BMI (11). This association can be explained by premature mechanical wear of joints associated with additional forces caused by the weight excess exerted on these joints (20). The average body mass index of our population was $25 \pm 2.66 \mathrm{~kg} / \mathrm{m}^{2}$ and more than half of them were overweight. But his fac- 
Table III - Determinants of MS-MSD after logistic regression.

\begin{tabular}{|l|l|c|c|c|}
\hline \multicolumn{2}{|c|}{} & p & OR & IC \\
\hline \multirow{2}{*}{$\begin{array}{l}\text { Sociodemographic } \\
\text { characteristics }\end{array}$} & Number of dependent children & 0.013 & 0.33 & $0.17-0.83$ \\
\cline { 2 - 5 } & Spouse at work & 0.05 & 0.35 & $0.12-0.99$ \\
\hline \multirow{4}{*}{$\begin{array}{l}\text { Professional } \\
\text { characteristics }\end{array}$} & Post of work & 0.00 & 4.16 & $1.95-8.88$ \\
\cline { 2 - 5 } & Professional qualification & 0.008 & 0.28 & $0.11-0.72$ \\
\cline { 2 - 6 } & Tacking a rest during work & 0.04 & 3.10 & $1.04-9.22$ \\
\cline { 2 - 6 } & Social Support & 0.00 & 7.1 & $1.9-25.3$ \\
\hline
\end{tabular}

tor was not associated with the risk of MSMSD in upper limbs.

Several published studies showed that the occurrence of MS-MSD was significantly correlated with the number of dependent children $(6,21)$, as in the case of Carvalho's study (22).

In our study, the number of dependent children was significantly associated with MS-MSD and this may be explained by an additional overload of domestic activities. Apart from occupational exposure to MSMSD, preexisting comorbidities may increase the risk of occurrence of these lesions (23).

Baillargeon and Patry explained in their book Work-related upper limb musculoskeletal disorders that people with rheumatic disease, neuromuscular diseases and psychiatric disorders are more likely to develop MSD when exposed to occupational risk factors. More specifically, they reported that hypothyroidism, diabetes mellitus and rheumatoid arthritis are factors that increase the risk of MS-MSD (24).

The main pre-existing conditions in our population were metabolic diseases in $18.5 \%$, hypertension $(9.1 \%)$, hypothyroidism $(4.7 \%)$ and depression (1.8\%).

In our study, there was no significant relationship between the pre-existence of comorbidities and the majority of MSD, which is inconsistent with some studies $(25,26)$.

According to some authors, and extending beyond the organic pathologies considered to be at risk of MS-MSD, personality type may interfere with the appearance of these lesions. Subjects with a high neuroticism score tend to introspection and somatic complaints (27). They would have an increased vulnerability to stress and a tendency towards job dissatisfaction, factors that appear associated with MSD of the neck and shoulders $(27,28)$.

In this study, $78 \%$ of the people worked in the confection sector. These results could be explained by a predominance of this sector in the study area. It represents 34\% of all manufacturing industries in Tunisia (29). In these activities, employees are exposed to repeated and rapid movements, often requiring a localized group of muscles and tendons, to maintain certain constraining postures that constitute risk factors for MSD (30-32).

However, in this study, the industrial sector was not correlated with MS-MSD involvement, which is inconsistent with the findings of Parot Schinckel E, which reported a higher prevalence of MS-MSD among food and manufacturing industries (33).

Further studies with a well-structured methodology will be required to identify the industrial sector most at risk of multiple MSD.

The post of clothing machine-worker was predominant $(41.3 \%)$ and it was retained among determinants of multifocal MSD. Similarly, Andersen $\mathrm{JH}$ et al. reported in their study of 424 machine workers that this workstation is significantly related to the onset and persistence of MSD-MS (34). According to some studies, occupational seniority increases the risk of MS-MSD. Reddy EM et al. reported in their study of 220 workers that occupational seniority had a significant influence on the occurrence of MS-MSD (35). Similarly, Liu. $\mathrm{J}$ et al. has noted among a large sample of workers that the onset of musculoskeletal disorders increases after more than ten years' professional tenure (36). In this study, the frequency of subjects suffering from MS-MSD increases clearly with occupational seniority and the risk of this pathology was significantly lower among skilled workers $(\mathrm{p}=0.016$, $\mathrm{OR}=0.43(\mathrm{CI}=0.22-0.85)$, explained by a better knowledge of preventive means and methods of carrying out tasks in qualified employees. These results are also noted in 
some studies $(1,37)$. Sérazin et al. reported in their study among 2287 employees that the occupational category influenced significantly the occurrence of musculoskeletal disorders (38).

Several scientific studies have found significant relationships between the occurrence of MSD and the lack of rest periods during labor $(39,40)$. Kim JH et al. reported in a study of 189 cameramen that $63.4 \%$ of them took a duration break $\leq 30$ min with a significant association of this factor with the risk of MS-MSD in a univariate study (11).

These findings were consistent with our results where the pause is a significant factor in the majority of musculoskeletal disorders $(\mathrm{p}=0.04, \mathrm{OR}=3.10, \mathrm{IC}=1.04-9.22)$.

Rest periods during work are a fundamental means of preventing MSD-MS, since they allow better recovery after strain (41). In addition, short and frequent breaks reduce muscle fatigue and static loads on the musculoskeletal system and reduce mood disturbances associated with long periods of labor.

In our study, the category of employee is more exposed to the risk of unilateral or multi-focal musculoskeletal involvement, which could reflect an unequal distribution of occupational risks between the different professional categories, documented by the DARES study. According to this study, employees are more exposed to physical constraints than public servants (39.1 vs $31.2 \%$ ) (42).

The status of employee or official is not associated with the occurrence of MS-MSD. These findings make it possible to conclude that, apart from biomechanical constraints, multifocal involvement of MSD is linked to other occupational factors, in particular psychosocial factors.

In this study, $90 \%$ of patients were in job stress situations significantly correlated with MS-MSD involvement. Similar findings have been described by some authors $(25,43)$. Sommer TG et al. reported in their study of 34,254 employees that the psychological state of job stress is significantly related to the majority of musculoskeletal disorders (44). Similarly, Neupane S et al. reported in a study of 734 employees that physical factors such as repetitive movements in association with psychosocial factors are significantly related to the multi-site involvement of MSD (45).

The complexity of explanatory models makes it difficult to determine occupational risk factors for MSD. Some authors also lead us to think that this distinction is hard to define methodologically. Bernard A and Guignon $\mathrm{N}$ noted, for example, that it is virtually impossible to distinguish precisely the relative importance of psychosocial and physical factors (46). However, psychosocial stresses are found in many work situations, which seems to suggest that they are general risk factors for MSD. Consequently, other high-quality methodological studies with stronger evidence will be needed to distinguish better the causal relationship between occupational risk factors for MSDs, in particular in its multi-site locations.

\section{CONCLUSIONS}

According to this study, multi-site involvement of MSD depends on individual, occupational and psychosocial factors. So preventive actions against MSD in companies cannot focus solely on physical or biomechanical exposure of operators as a means of confronting this problem.

When individual risk factors are fixed, the prevention of multi-site MSD-MS must target the modifiable levers that constitute the employee's professional environment. This approach must follow a well-structured occupational risk management policy.

Conflict of interest: The authors declare that they have no conflict of interest in relation to this article.

\section{REFERENCES}

1. Réseau expérimental de surveillance épidémiologique des troubles musculo-squelettiques dans les Pays de la Loire. Surveillance en entreprises en 2002. Available from: http://invs. santepubliquefrance.fr

2. Institut de santé et de sécurité au travail - ISST Tunisie.

3. Guide pratique: Démarche de prévention des 
troubles musculo-squelettiques (TMS). Available from: http://www.fonction-publique.gouv.fr

4. Karasek R, Brisson C, Kawakami N, Houtman I, Bongers P, Amick B. The Job Content Questionnaire (JCQ): an instrument for internationally comparative assessments of psychosocial job characteristics. J Occupat Health Psychol. 1998; 3: 322-55.

5. Da Costa BR, Vieira ER. Risk factors for work-related musculoskeletal disorders: A systematic review of recent longitudinal studies. Am J Ind Med. 2010; 53: 285-323.

6. Pelissier C, Fontana L, Fort E, et al. Occupational risk factors for upper-limb and neck musculoskeletal disorder among health-care staff in nursing homes for the elderly in France. Ind Health. 2014; 52: 334-46.

7. Ekpenyong CE, Inyang UC. Associations between worker characteristics, work place factors, and work-related musculoskeletal disorders: a cross-sectional study of male construction workers in Nigeria. Int J Occupat Safety Ergon. 2014; 20: 447-62.

8. Risques professionnels: les femmes sont-elles à l'abri? Available from: http://www.insee.fr

9. Solidaki E, Chatzi L, Bitsios P, et al. Workrelated and psychological determinants of multisite musculoskeletal pain. Scand J Work Environ Health. 2010; 36: 54-61.

10. Kim T, Roh H. Analysis of risk factors for work-related musculoskeletal disorders in radiological technologists. J Phys Ther Sci. 2014; 26: 1423-8.

11. Ho KJ, Seong SB, Kim SG, et al. Risk factors of work-related upper extremity musculoskeletal disorders in male cameramen. Ann Occupat Environ Med. 2015; 27 : 5.

12. Loi $n^{\circ}$ 94-28 du 21 février 1994 portant régime de réparation des préjudices résultant des accidents du travail et des maladies professionnelles. Available from: http://www.ilo.org

13. Karasek RA. Job demands, job decision latitude, and mental strain: implications for job redesign. Admin Sci Q. 1979; 24: 285-308.

14. Wang P-C, Rempel DM, Harrison RJ, et al. Work-organisational and personal factors associated with upper body musculoskeletal disorders among sewing machine operators. Occup Environ Med. 2007; 64: 806-13.

15. Maladies professionnelles: les femmes plus exposées. Available from: http://www.alternatives-economiques.fr

16. Genre et TMS: quand les différences biologiques masquent les effets de la division sexuelle du travail. Available from: https:// www.eesp.ch

17. Enquête sociale et de santé 1998. Available from: http://www.stat.gouv.qc.ca

18. Troubles musculosquelettiques de l'épaule (tendinite). Available from: http://www.passeportsante.net/fr
19. Alexopoulos EC, Stathi I-C, Charizani F. Prevalence of musculoskeletal disorders in dentists. BMC Musculoskel Dis. 2004; 5: 16.

20. Quand le poids pèse sur les articulations. Available from: http://www.e-sante.be

21. Sadeghian F, Kasaeian A, Noroozi P, et al. Psychosocial and individual characteristics and musculoskeletal complaints among clinical laboratory workers. Int J Occupat Safety Ergon. 2014; 20: 355-61.

22. Carvalho D, Peres M, Schmidt LG, Soares MCF. Musculoskeletal disorders and their influence on the quality of life of the dock worker: A cross-sectional study. Work. 2016; 53: 805-12.

23. Andersen JH, Haahr JP, Frost P. Risk factors for more severe regional musculoskeletal symptoms: a two-year prospective study of a general working population. Arthritis Rheum. 2007; 56: 1355-64.

24. Les troubles musculo-squelettiques du membre supérieur reliés au travail. Available from: http://www.cubiq.ribg.gouv.qc.ca

25. Solidaki E, Chatzi L, Bitsios P, et al. Risk factors for new onset and persistence of multi-site musculoskeletal pain in a longitudinal study of workers in Crete. Occup Environ Med. 2013; 70: 29-34.

26. Airila A, Hakanen JJ, Luukkonen R, et al. Developmental trajectories of multisite musculoskeletal pain and depressive symptoms: the effects of job demands and resources and individual factors. Psychol Health. 2014; 29: 1421-41.

27. McCrae RR, Costa PT. Validation of the fivefactor model of personality across instruments and observers. J Pers Soc Psychol. 1987; 52: 81-90.

28. Hansell S, Mechanic D. Introspectiveness and adolescent symptom reporting. J Human Stress. 1985; 11: 165-76.

29. Monographies sectorielles - Tunisie Industrie. Available from: http://www.tunisieindustrie. nat.tn/fr

30. Mrabet Bahri D, Khiari H, Gmati A, et al. Carpal tunnel syndrome. A Tunisien series. Tunis Med. 2012; 90: 62-5.

31. Van Rijn RM, Huisstede BMA, Koes BW, Burdorf A. Associations between work-related factors and the carpal tunnel syndrome--a systematic review. Scand J Work Environ Health. 2009; 35: 19-36.

32. Wærsted M, Hanvold TN, Veiersted KB. Computer work and musculoskeletal disorders of the neck and upper extremity: A systematic review. BMC Musculoskel Dis. 2010; 11: 79.

33. Parot-Schinkel E. Etude des troubles musculosquelettiques multi-sites: Données en population salariée dans les Pays de la Loire. Available from: https://tel.archives-ouvertes.fr/

34. Andersen JH, Gaardboe O. Prevalence of per- 
sistent neck and upper limb pain in a historical cohort of sewing machine operators. Am J Ind Med. 1993; 24: 677-87.

35. Reddy EM, Yasobant S. Musculoskeletal disorders among municipal solid waste workers in India: A cross-sectional risk assessment. J Family Med Primary Care. 2015; 4: 519-24.

36. Liu J, Huang G, Li X, et al. Study on prevalence of occupational musculoskeletal disorders and the risk factors among workers in three industries in Zhongshan, China. Zhonghua Lao Dong Wei Sheng Zhi Ye Bing Za Zhi. 2014; 32: 415-7.

37. Sérazin C, Ha C, Bodin J, et al. Employment and occupational outcomes of workers with musculoskeletal pain in a French region. Occup Environ Med. 2013; 70: 143-8.

38. Devenir professionnel des salariés des Pays de la Loire souffrant de troubles musculosquelettiques. Available from: http://www. camip.info

39. Neupane S. Multi-site Musculoskeletal Pain among Industrial Workers Occurrence, determinants and consequences for work ability and sickness absence; 2012. Available from: tampub.uta.fi

40. Bongers PM, de Winter CR, Kompier MA, Hildebrandt VH. Psychosocial factors at work and musculoskeletal disease. Scand J Work Environ Health. 1993; 19: 297-312.
41. Henning RA, Jacques P, Kissel GV, et al. Frequent short rest breaks from computer work: effects on productivity and well-being at two field sites. Ergonomics 1997; 40: 78-91.

42. L'exposition des salariés aux maladies professionnelles en; 2007. Available from: http:// dares.travail-emploi.gouv.fr

43. Herin F, Vézina M, Thaon I, et al. Predictive risk factors for chronic regional and multisite musculoskeletal pain: a 5-year prospective study in a working population. Pain. 2014; 155: 937-43.

44. Sommer TG, Frost P, Svendsen SW. Combined musculoskeletal pain in the upper and lower body: associations with occupational mechanical and psychosocial exposures. Int Arch Occup Environ Health. 2015; 88: 1099110.

45. Neupane S, Miranda H, Virtanen P, et al. Do physical or psychosocial factors at work predict multi-site musculoskeletal pain? A 4-year follow-up study in an industrial population. Int Arch Occup Environ Health. 2013; 86: 581-9.

46. Arnaudo B, Guignon N. Présentation des résultats de l'enquête française SUMER, à propos des facteurs de risque de TMS. Acte du 2ème Congrès francophone sur les troubles musculo-squelettiques: de la recherche à l'action; 18 et 19 juin 2008; Montréal, Canada. Available from: http://www.irsst.qc.ca 